\title{
VENEREAL DISEASE IN LITERATURE
}

\author{
By DR. J. D. ROLLESTON
}

\section{Discussion}

Sir D'ARcy Power said he was sure everyone present had listened with very great pleasure to Dr. Rolleston's learned and interesting address.

He was perfectly sure that there was no syphilis before the discovery of America, about I493. He had looked through various books, such as the works of Boccaccio and Villon, and "Gil Blas," and he had found hardly any reference to venereal disease in them. The only one he had come across was in the " Epistolæ Obscurorum Virorum," which he thought was the most amusing skit one could possibly have, published in I5I5. The book was contributory to the Reformation in Germany, and it consisted of a series of letters written in dog Latin ostensibly by obscure people. It was full of the most amusing jokes. The copy shown that evening was bound in a Prayer-book cover, and it was evident that the owner of it, about 1556 , used to take it to church with him and sit in the choir and read it. It contained one reference to venereal disease, where it said of a particular man " that he had tainted all the trulls in Italy."

That raised the question as to when venereal disease came to be considered immoral or amoral. Evidently there must have been a large amount of gonorrhœea and soft sores, as Dr. Rolleston had said, but apparently no moral reprehension was attached to the disease and, for that reason, people thought little or nothing of it; it must have been considered a comparatively trivial disease. It was well known that, as Dr. Rolleston had mentioned, syphilis was called pox, to distinguish it from gonorrhœa, because the term gonorrhœa was used etymologically for any discharge from the genital organs and included a discharge from a tuberculous kidney or from cystitis or spermatorrhœa or anything that was purulent, chaude pisse certainly went back as far as 1376, because cures were mentioned for it at that date. 


\section{BRITISH JOURNAL OF VENEREAL DISEASES}

Even as late as the time of John Ward, who was Vicar of Stratford-on-Avon in I662, no moral obliquity was attached to venereal disease. The Rev. John Ward, M.A., treated several of his parishioners for gonorrhœa, and did not attach the least moral obliquity to it : he merely took it as a matter of course.

Sir D'ARCY hoped that Dr. Rolleston in his reply would say when any moral reprehension was attached to venereal disease, so that it was looked upon as a direct punishment for sexual sin. In his youth it was not mentioned at all in respectable families, nor even spoken of very much amongst medical students. It was kept secret, and people did not have treatment for it. It was only lately that it had come out into the open again. Perhaps Dr. Rolleston might go even further and state what the present position was in regard to the matter, as he did not know of his own knowledge.

Dr. Norman said Dr. Rolleston had mentioned the name of John Young Simpson, but the speaker thought it should have been James Young Simpson, who was a great archæologist as well as having had much to do with the introduction of anæsthetics.

$\mathrm{He}$ was interested in the "Epistolæ Obscurorum Virorum," a most entertaining work. Dr. Rolleston had referred to Ulrich von Hutten and the fact that he suffered from venereal disease; and personally he understood that Ulrich von Hutten was chiefly responsible for the "Epistolæ," if he did not write them completely.

He wished he had gone still further in keeping a common-place book and noted down the references he came across to venereal disease, because they were very frequent. Although Dr. Rolleston had read a very learned and comprehensive paper, he himself, in looking through one or two works of the eighteenth century, had found certain further references. He was interested in Dr. Cotton of St. Albans, who lived practically through the eighteenth century and was mentioned in the "Dictionary of National Biography" as having written one medical work: he really wrote two such works. Dr. Cotton was a very godly man and wrote a great deal of poetry which he published anonymously-he did not know whether Dr. Cotton was ashamed of it-and which had a great vogue. One of his works was called "Visions 


\section{VENEREAL DISEASE IN LITERATURE}

in Verse," and in looking through it he had come upon the following lines in one of the Visions, called Happiness.

\footnotetext{
" A mangled youth, beneath a shade

A melancholy scene displayed :

His noseless face and loathsome stains

Proclaim'd the poison in his veins :

He rais'd his eyes, he smote his breast,

He wept aloud, and thus address'd :

' Forbear the harlot's false embrace,

Tho' Lewdness wears an angel's face.

Be wise, by my experience taught :

I die, alas! for want of thought.
}

He might add that the "Visions in Verse " were written "For the Entertainment and Instruction of Younger Minds." They were rather grim, he thought, and the "Younger Minds" must have taken a more solemn view of life in those days than they did at the present time!

Referring to the interesting exhibit of books provided by Dr. Rolleston and Sir D'Arcy Power, he said that book collectors sometimes did extraordinarily eccentric things, and spent large sums of money on them. Personally, he had been collecting works ending in " ad," starting with the "Dunciad," and he had found it extremely interesting. He had been surprised at the number of them : there were all sorts of them about all kinds of things. There was one published in I76I called "The Meretriciad." The anonymous author of it spoke about the ladies of the town, and addressed one of them by the appropriate name of " French," saying :-

" Thy deeds, O French! deserve an abler pen,

To paint thy devastations brought on men :

Tho. thou art living, yet they're obsolete,

If ought perpetuates, it's some endless gleet :

You had your hot, nay, and your Cold-well too,

And he that dabbl'd did his dabble rue :

I know you shone, I know you knew to please,

And pickle some too with the French disease."

He had found another reference in a book called " Wynter's Whims," which contained a series of epigrams and satiric verses. One was addressed to "Mr. L."

“ In getting Maidenheads, to get the Pox

What is't but breaking open Pandora's Box ?"

The author of "The Meretriciad " followed it up with "The Courtesan," in which he thought there was an obvious reference to syphilis. 


\section{BRITISH JOURNAL OF VENEREAL DISEASES}

"But why should I torment thee with this strain ?

That hair is dropt-and ne'er may grow again :

The fatal cause I would not, dare not, guess,

It was not poison-and 'twas nothing less :

I will not say-I'm sure you're full of care,

The omen's bad-the falling of the hair :

Be this a warning-time will speed'ly show

Whether dear Cambridge-thy dear hair will grow."

The reference made by Dr. Rolleston to "Taliacotius" and his operations brought back to his mind a passage in Butler's "Hudibras," where Butler described the nose being made from a porter's posterior.

He had been extremely interested in Dr. Rolleston's paper, and looked forward with great interest to reading it when it appeared in print.

Professor WilloughBy said he had been interested to hear of the references to venereal disease in German literature. He had been struck by the fact that there were so few, and had asked himself whether that was due to the fact that the Germans were a particularly moral race. No doubt Herr Hitler would say so. But the speaker could hardly ascribe it to that, because Dr. Rolleston referred to two important German writers in the sixteenth century, to Sebastian Brandt, who wrote, "das Narrenschiff," and Ulrich von Hutten, who was largely responsible for that amusing satire the " Epistolæ Obscurorum Virorum," directed mainly against the Theological faculty of the University of Cologne. It was one of the most amusing books of the time, full of good stories and anecdotes, making fun of the general ineptitude and ignorance of the learned doctors of Cologne. One story denied that Julius Cæsar wrote the "Commentaries," for such a busy man could never have found time to learn Latin! Perhaps there were some other German works in which references to venereal disease could be found.

In the seventeenth century there were definite references to the venereal disease in the great novel of the Thirty Years' War, "Simplicius Simplicissimus " and its continuations. Simplicius himself suffers from the disease as a result of his caresses in Paris.

It was, of course, a literature inspired by the great picaresque or rogue novel of an earlier period, a good deal of which came from Romance sources.

It had occurred to him that there was one indirect 


\section{VENEREAL DISEASE IN LITERATURE}

reference to syphilis in Goethe's "Faust," where Mephistopheles told Martha about the death of her husband, and referred to the ladies of Naples, saying that they had done him an injury and he had squandered the goods he should have brought home to his loving wife and children. One saw from that how the tradition of Neapolitan disease persisted in Goethe's day.

He did not remember whether there was any reference in Wedekind, but that was a possibility, and that author might prove a fruitful source of such references; he meant in "Die Büchse der Pandora," the story of the prostitute who was murdered by " Jack the Ripper" in London. He thought there was a reference there, but at the moment he could not be sure.

He was very much interested in the subject of Dr. Rolleston's paper on its literary side, although naturally not competent to deal with its medical aspect, and he looked forward to seeing a copy of it in print. He meant, one day, to persuade Dr. Rolleston to talk to the Goethe Society about the medical history of Goethe-he was not for a moment suggesting that Goethe suffered from venereal disease but it was a subject which, he knew, had occupied Dr. Rolleston for some years, and concerning which we in England had very little information.

Dr. F. PARKes Weber, referring to Dr. Rolleston's statement that there were no allusions to tabes and general paralysis before the nineteenth century, said there were certainly many of them in the nineteenth century, but he would like to know when the connection between tabes and general paralysis with syphilis was first acknowledged. He was aware it had not been proved until comparatively recently. He remembered that when he heard Dr. Charcot's lectures in Paris Dr. Charcot did not regard it as a matter proved that tabes was necessarily due to syphilis, though soon afterwards the connection was proved. It was remarkable that anyone should have thought of the connection. He believed that until quite recently some of the South Sea Islanders did not understand that children were born as a result of sexual connection. On the other hand, all kinds of things, such as ordinary male baldness, had been ascribed to sexual excess or sexual disease which were now known to have little if anything to do with either of them. 


\section{BRITISH JOURNAL OF VENEREAL DISEASES}

He would particularly like to hear if Dr. Rolleston knew when the connection between general paralysis and tabes with syphilis was first seriously suggested.

Dr. W. Rushton Parker suggested that before Dr. Rolleston's paper was published he might include some reference to ancient Egypt, because so much was known about the history of many different dynasties, and also because many Egyptian mummies had been carefully dissected. He did not think there was any evidence or suspicion of syphilis amongst the ancient Egyptians. Considering the large number of mistresses that Rameses II. had, he ran a considerable risk of contracting syphilis if there was any about.

He would also like to see in the paper a little more of the evidence that might be obtainable with regard to congenital syphilis. For instance, it was generally supposed that Henry VIII. must have had syphilis, but the speaker had recently read that this idea was a mistake. Mary Queen of Scots is said to have refused Darnley permission to be present at the christening of her child, James I., because he was " pocky," and to have refused to allow Cardinal Beaton to christen the child, because he was a " pocky priest."

During the last ten years the speaker had been travelling through many parts of the world, and had taken every opportunity of visiting leper hospitals. In those hospitals, in many parts of the world, the staff had told him that they could not make out how much of the disease with which they were dealing was due to leprosy, and how much to syphilis. They seemed to think that most lepers had syphilis also.

The PRESIDENT said he was sure all present had listened with the greatest interest and pleasure to Dr. Rolleston's paper, and they were very much indebted to him for giving such a learned and comprehensive contribution on the subject of Venereal Disease in Literature.

In the references to venereal disease in the Bible which the reader gave he had not mentioned the sins of the fathers being visited on the children. That was sometimes taken to be a reference to the transmission of venereal disease to children; in fact he had seen it mentioned in a book on congenital syphilis as evidence that the disease was transmitted from generation to generation. The speaker was one of those who believed 


\section{VENEREAL DISEASE IN LITERATURE}

that syphilis could be transmitted to the third generation; he did not know as to the fourth and fifth generations. The reference, of course, might be to hereditary diseases in general, not to venereal disease.

With regard to tabes and G.P.I., it was not surprising that one found no reference in literature to tabes or G.P.I. in connection with syphilis ; as Dr. Parkes Weber had pointed out, it was very difficult to associate syphilis with those conditions, as they might occur many years after the primary lesion, and it was only when the Wassermann reaction was discovered that proof was forthcoming. He supposed it was Fournier who first insisted upon the relation between syphilis and G.P.I. When the speaker was a student it was not considered by any means certain that G.P.I. was always syphilitic.

With regard to Oswald, in Ibsen's " Ghosts," to which the lecturer referred, he thought the symptoms described were not quite those of juvenile G.P.I., but rather those of meningo-vascular syphilis.

Dr. Rolleston, in reply, said he had greatly enjoyed the evening, and thanked members warmly for the welcome they had extended to him. He would probably have been squashed flat if his friend, Professor Singer, had been present, as that gentleman firmly believed that syphilis existed in the Middle Ages, though he did not think it existed in classical antiquity or in Biblical times. Professor Singer believed that the outbreak of disease which occurred at the end of the fifteenth century was. not syphilis, but paratyphoid fever. The speaker thought that all the best people held the opposite view !

He was unable to answer Sir D'Arcy Power's question as to when people exposing themselves to the chance of venereal infection came first to regard it as shameful. It was only comparatively recently that a more humane view had been adopted, due, he supposed, to Osler to a great extent. He remembered causing quite a sensation when he was a student, when asked to give the causes of fever, by blurting out "Syphilis." He thought that Fournier also, owing to the humane attitude he took up with regard to syphilis, was responsible for the recent change of view. He had been particularly struck by a passage in Fournier's works about the moral stigma attaching to syphilis, in which he said that if everybody who had not exposed themselves to infection were to 


\section{BRITISH JOURNAL OF VENEREAL DISEASES}

throw stones at the man who had contracted syphilis, there would not be much fear of the man suffering from une lapidation bien confluente.

With regard to Dr. Norman's remark about Simpson, he, the speaker, had referred merely to " Young Simpson," but he thought that J. Y. Simpson was the Professor of Obstetrics who once came down, at a very advanced age, to read a paper on Astruc before the History of Medicine Section at the Royal Society of Medicine.

He remembered well the passage which had been quoted from Butler's " Hudibras," but it was the monosyllable which was used, not the longer word.

In reply to Dr. Parkes Weber, he had always been under the impression that it was Erb and Fournier who made out that tabes and general paralysis were connected with syphilis.

He was conscious that his paper was not complete, but he confessed to an entire ignorance of Egyptology. He had hoped that his friend, Mr. Warren Dawson, who was an Egyptologist, would have been present. In the time allotted to him he could not, of course, dwell upon the possible prevalence of syphilis in all countries.

With regard to Professor Willoughby's very interesting remarks, Goethe was supposed to have contracted syphilis. He believed that suggestion was made by Dr. Freund, who thought Goethe led a somewhat wild life in Leipzig, Strasbourg and elsewhere, and no doubt, exposed himself to infection. Goethe had a mysterious disease associated with swelling of the glands of the neck, which was probably tuberculous. $\mathrm{He}$ lived to an advanced age, and certainly never showed any signs of tabes or general paralysis.

In reply to Dr. Rushton Parker's question, he, Dr. Rolleston, was under the impression that it was syphilis from which Henry VIII. suffered.

On the motion of the President, Dr. Rolleston was very cordially thanked for his address. 